\title{
Editorial
}

\section{Phycology: Algae for Food, Feed, Fuel and the Planet}

\author{
Peer M. Schenk (D)
}

Citation: Schenk, P.M. Phycology: Algae for Food, Feed, Fuel and the Planet. Phycology 2021, 1, 76-78. https: / / doi.org/10.3390/ phycology1010005

Received: 4 September 2021 Accepted: 6 September 2021 Published: 10 September 2021

Publisher's Note: MDPI stays neutral with regard to jurisdictional claims in published maps and institutional affiliations.

Copyright: (C) 2021 by the author. Licensee MDPI, Basel, Switzerland. This article is an open access article distributed under the terms and conditions of the Creative Commons Attribution (CC BY) license (https:/ / creativecommons.org/licenses/by/ $4.0 /)$.
School of Agriculture and Food Sciences, University of Queensland, Brisbane, QLD 4072, Australia; p.schenk@uq.edu.au

I often like to tell my students: "It does not matter what the question is, "algae" is the answer." Indeed, I am convinced that algae (microalgae/cyanobacteria and macroalgae/seaweed) and knowledge in Phycology will be essential for humanity to prevail. Why is Phycology, the study of algae, so important?

There is no doubt about the important ecological role of algae. They are responsible for most of the oxygen in the atmosphere and about half of the Earth's current oxygen production [1,2].

As mostly primary producers in aquatic (and terrestrial) systems, they form the basis of the food chain and are hence absolutely essential for life on this planet. Apart from their important historical and ecological role, they also have the potential to address most of the global issues of our times. This is because algae are the most productive photosynthetic organisms in the world [1]. Importantly, and unlike most other "crops", their cultivation does not need to compete for arable land, biodiverse ecosystems or freshwater resources [3]. This opens the door for sustainable large-scale cultivation. How can this address our global issues, such as Food Security, Human Health, Water Security, Energy Security, and the Environment (including Climate Change)? I would like to provide some examples.

Algae and Food Security: Our own work has confirmed that microalgae can produce approx. 70 times more protein per hectare than soybean [4], the most commonly used protein source for food and feed. It appears, therefore, that simply increasing more algal products in our diet and in animal feed can relieve important pressure on arable land and biodiverse landscapes (such as rainforests). The biggest challenge here is to make them cost-competitive. In my view, this can be achieved through (1) technology improvements in cultivation, harvesting and processing (e.g., automation and artificial intelligence), (2) coupling to other industries that can provide resources $\left(\mathrm{CO}_{2}\right.$ emitters, nutrient-rich wastewater), (3) algal strain improvements by adaptation and using them as microbial biofactories through synthetic biology.

Algae and Human Health: The biggest human health issue is probably malnutrition [5]. Many algae contain all that is needed for human nutrition (energy in the form of starch/lipids, protein with essential amino acids, dietary fibre, minerals, vitamins and antioxidants; [6,7]). Several nutraceuticals are already routinely produced from algae, including phycocyanin, omega-3 fatty acids, carotenoids (e.g., beta-carotene, fucoxanthin, astaxanthin), polysaccharides, and several other bioactive compounds. In addition, microalgae are being used as microbial biofactories to produce medicines and other bioactives.

Algae and Water Security: Algae (microalgae, macroalgae/seaweeds) play an important role in natural water purification and bioremediation [8]. This is mainly achieved through their ability to rapidly take up nutrients and produce oxygen, but this can also lead to issues of eutrophication when algae blooms become light- or nutrient-limited and heterotrophic algae-consuming organisms deplete oxygen (leading to partial or complete anaerobiosis). A regular removal of algal biomass is therefore required when using algae for bioremediation from nutrient-rich waters. Algae can also be used for bioremediation of contaminated waters, e.g., for heavy metal uptake [9], a feature of algae that should be checked when using algal biomass for food or feed. 
Algae and Energy Security: Although we are currently experiencing an energy transition towards renewables, it should be considered that nearly all of these are in the form of electricity, while the majority of energy consumption still comes from stored energy (mostly fossil fuels). Fuel (such as diesel) is about 20 times more energy-dense than current batteries, and even when most vehicles will be electric, fuels are still required for energy storage and most weight-sensitive transport (e.g., in aviation). First generation biofuels, although renewable in principle, compete with food production and biodiverse landscapes [3]. Algae have been proposed as biofuel feedstocks without these issues and can even serve as "solar power plants to sustainably produce fuel" when coupled with nutrient recycling of defatted biomass [10]. However, the current relatively low cost of fossil fuel makes it hard to compete. To realise algae's biofuel potential, a co-generation of more valuable products is needed in a biorefinery, (e.g., biodiesel from lipids coupled to alternative, vegan protein produced for human consumption from defatted biomass).

Algae and the Environment: Algae play a central and essential role for biodiversity, nutrient cycling and ecosystem services in nearly all environments, affecting most forms of life in one way or another [2]. Their importance ranges from roles as key symbionts (e.g., with corrals or in lichens), to being the basis of food chains, to ecosystem services, and microbiome functions (e.g., soil crusts, aquatic microbiomes). Regarding $\mathrm{CO}_{2}$-mediated global warming and ocean acidification, algae play a key role as the most effective $\mathrm{CO}_{2}$ assimilators and as potential carbon sinks [11]. Examples of their role in carbon sequestration are provided through large-scale seaweed production with sequestration to the bottom of the ocean, cultivation on areas that do not compete for arable land or biodiversity (e.g., co-production of protein and sequestrable biochar), or as feed supplement to reduce methane emissions from ruminant livestock.

I do hope that you share my enthusiasm for Phycology and that you will contribute to this new journal by providing new insights into the important role of algae in ecology, but also the enormous potential in biotechnological applications and industry. The environmental, economic and societal gains from research in Phycology can be significant, and Phycology (ISSN 2673-9410) [12], aims to be a gateway for publishing new and exciting research in this area.

Phycology covers all fundamental and applied topics associated with algae, including all ecological, physiological, genetic and biotechnological aspects of cyanobacteria, eukaryotic microalgae, macroalgae and seaweed. The journal is international, peer-reviewed, and open access, and aims to inspire scientists, engineers and scholars to publish their significant new results in great detail with no restrictions on manuscript length. I hope that this new journal will provide the platform needed to provide algae the attention they deserve to generate the fundamental and applied knowledge that can address our global issues. I expect that Phycology will generate a broad readership that recognises the curiosity, excitement, and significance of algae for our changing world.

In this inaugural issue, you will find new knowledge and technology on algae for carbon sequestration, environmental management, algal reproductive biology and biodiversity/conservation. Funding: This research was funded by The University of Queensland.

Institutional Review Board Statement: Not applicable.

Informed Consent Statement: Not applicable.

Data Availability Statement: Not applicable.

Conflicts of Interest: The author declares no conflict of interest.

\section{References}

1. Kasting, J.F.; Siefert, J.L. Life and the evolution of Earth's atmosphere. Science 2002, 296, 1066-1068. [CrossRef] [PubMed]

2. Pereira, L.; Neto, J.M. (Eds.) Marine Algae: Biodiversity, Taxonomy, Environmental Assessment, and Biotechnology; CRC Press: Boca Raton, FL, USA, 2014. 
3. Correa, D.F.; Beyer, H.L.; Fargione, J.E.; Hill, J.D.; Possingham, H.P.; Thomas-Hall, S.R.; Schenk, P.M. Towards the implementation of sustainable biofuel production systems. Renew. Sustain. Energy Rev. 2019, 107, 250-263. [CrossRef]

4. MLA Report. Available online: https://www.mla.com.au/contentassets/dde70bd0801f48ae829979bd333fe141/b.nbp.0695_final_ report.pdf (accessed on 3 September 2021).

5. Müller, O.; Krawinkel, M. Malnutrition and health in developing countries. Cmaj 2005, 173, 279-286. [CrossRef] [PubMed]

6. Wells, M.L.; Potin, P.; Craigie, J.S.; Raven, J.A.; Merchant, S.S.; Helliwell, K.E.; Smith, A.G.; Camire, M.E.; Brawley, S.H. Algae as nutritional and functional food sources: Revisiting our understanding. J. Appl. Phycol. 2017, 29, 949-982. [CrossRef] [PubMed]

7. Kratzer, R.; Murkovic, M. Food ingredients and nutraceuticals from microalgae: Main product classes and biotechnological production. Foods 2021, 10, 1626. [CrossRef] [PubMed]

8. Mohsenpour, S.F.; Hennige, S.; Willoughby, N.; Adeloye, A.; Gutierrez, T. Integrating microalgae into wastewater treatment: A review. Sci. Total Environ. 2020, 752, 142168. [CrossRef] [PubMed]

9. Chekroun, K.B.; Baghour, M. The role of algae in phytoremediation of heavy metals: A review. J. Mater. Environ. Sci. 2013, 4, 873-880.

10. González-González, L.M.; Correa, D.F.; Ryan, S.; Jensen, P.D.; Pratt, S.; Schenk, P.M. Integrated biodiesel and biogas production from microalgae: Towards a sustainable closed loop through nutrient recycling. Renew. Sustain. Energy Rev. 2018, 82, 1137-1148. [CrossRef]

11. Krause-Jensen, D.; Duarte, C.M. Substantial role of macroalgae in marine carbon sequestration. Nat. Geosci. 2016, 9, 737-742. [CrossRef]

12. Phycology Home Page. Available online: https://www.mdpi.com/journal/phycology (accessed on 3 September 2021).

\section{Short Biography of Author}

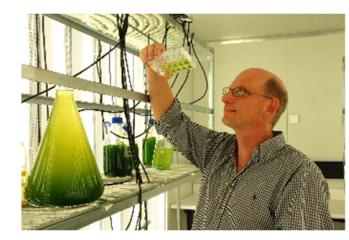

Peer Schenk is Professor for Plant and Microbial Biotechnology in the School of Agriculture and Food Sciences at the University of Queensland, Australia and heads the Algae Biotechnology Laboratory at UQ since 2004. Prior to that, he completed his PhD at the Max Planck Institute for Breeding Research in 1994 and has since been Project and Program Leader in four Cooperative Research Centres that promote collaboration between industry and academia. Prof. Schenk discovered and commercialised fundamental new concepts and technology from Plant-Microbe Interactions, Algal Biotechnology and Water Purification, leading to several start-up companies in these areas. He was Australia's APEC representative for biorefinery concepts and produced plant varieties that are now commercially grown in three continents. His team established the UQ Algae Energy Farm in 2013, a large-scale algae farm that develops and demonstrates new cost-saving technologies to produce food, feed, nutraceuticals and biofuel from algae. 